\title{
How strong is the current carbon sequestration of an Atlantic blanket bog?
}

\author{
ANN-KRISTIN KOEHLER, MATTEO SOTTOCORNOLA ${ }^{1}$ and GERARD KIELY \\ Centre for Hydrology, Micrometeorology and Climate Change, Department of Civil and Environmental Engineering, \\ University College Cork, Cork, Republic of Ireland
}

\begin{abstract}
Although northern peatlands cover only $3 \%$ of the land surface, their thick peat deposits contain an estimated onethird of the world's soil organic carbon (SOC). Under a changing climate the potential of peatlands to continue sequestering carbon is unknown. This paper presents an analysis of 6 years of total carbon balance of an almost intact Atlantic blanket bog in Glencar, County Kerry, Ireland. The three components of the measured carbon balance were: the land-atmosphere fluxes of carbon dioxide $\left(\mathrm{CO}_{2}\right)$ and methane $\left(\mathrm{CH}_{4}\right)$ and the flux of dissolved organic carbon (DOC) exported in a stream draining the peatland. The 6 years $\mathrm{C}$ balance was computed from 6 years (2003-2008) of measurements of meteorological and eddy-covariance $\mathrm{CO}_{2}$ fluxes, periodic chamber measurements of $\mathrm{CH}_{4}$ fluxes over 3.5 years, and 2 years of continuous DOC flux measurements. Over the 6 years, the mean annual carbon was $-29.7 \pm 30.6( \pm 1 \mathrm{SD}) \mathrm{gC} \mathrm{m}^{-2} \mathrm{yr}^{-1}$ with its components as follows: carbon in $\mathrm{CO}_{2}$ was a sink of $-47.8 \pm 30.0 \mathrm{~g} \mathrm{C} \mathrm{m}^{-2} \mathrm{yr}^{-1}$; carbon in $\mathrm{CH}_{4}$ was a source of $4.1 \pm 0.5 \mathrm{~g} \mathrm{C} \mathrm{m}^{-2} \mathrm{yr}^{-1}$ and the carbon exported as stream DOC was a source of $14.0 \pm 1.6 \mathrm{~g} \mathrm{C} \mathrm{m}^{-2} \mathrm{yr}^{-1}$. For 2 out of the 6 years, the site was a source of carbon with the sum of $\mathrm{CH}_{4}$ and DOC flux exceeding the carbon sequestered as $\mathrm{CO}_{2}$. The average $\mathrm{C}$ balance for the 6 years corresponds to an average annual growth rate of the peatland surface of $1.3 \mathrm{~mm} \mathrm{yr}^{-1}$.
\end{abstract}

Keywords: carbon balance, carbon sequestration, dissolved organic carbon, methane, net ecosystem exchange, peatland

Received 11 November 2009 and accepted 23 December 2009

\section{Introduction}

Northern peatlands account for about $3 \%$ of the earth's land area and have accumulated 20\%-30\% of the world's estimated global soil carbon (C) pool which corresponds to 270-450 Pg of C (Gorham, 1991; Turunen et al., 2002). A recent study reported that the northern circumpolar permafrost region contains approximately $50 \%$ of the global belowground organic carbon pool (Tarnocai et al., 2009). Peatlands are generally less productive than other ecosystems making their contribution to the current terrestrial exchange relatively small $\left(\approx 0.1-0.5 \mathrm{PgC} \mathrm{yr}^{-1}\right.$ compared with $\approx 60 \mathrm{PgCyr}^{-1}$ for the net terrestrial exchange, Schimel, 1995) so that it is more the future of their large soil $\mathrm{C}$ pool to be of concern (Moore et al., 1998). Globally only 3\% of the peat area is covered by blanket bogs, but locally they can be very important. In the Republic of Ireland blanket bogs cover about $13 \%$ of the land area containing an estimate of about $28 \%-45 \%$ of the nation soil C

Correspondence: Ann-Kristin Koehler, tel. + 35321 4903025, fax

+ 35321 4276648, e-mail: a.koehler@student.ucc.ie

${ }^{1}$ Present address: M. Sottocornola, IASMA Research and Innovation Centre, Fondazione Edmund Mach - Environment and Natural Resources Area, Loc. Viote del Bondone, 38100 Trento, Italy. stock (Tomlinson, 2005; Eaton et al., 2008). Blanket bogs are largely ombrotrophic peatlands, thus receive water and nutrients only through atmospheric deposition and typically develop independently from basins in temperate regions with annual rainfall greater than $1250 \mathrm{~mm}$ (Hammond, 1981).

The net ecosystem carbon balance (NECB, after Chapin III et al., 2006) of peatlands comprises: net ecosystem exchange (NEE, the difference between fixation of $\mathrm{C}$ via photosynthesis and emission of $\mathrm{C}$ through ecosystem respiration); net methane $\left(\mathrm{CH}_{4}\right)$ consumption or efflux; and the net gain or loss of $\mathrm{C}$ in water inputs and runoff (including total organic carbon, dissolved inorganic carbon and $\mathrm{CH}_{4}$ ). There are only few peatland NEE studies that are extended for more than 1 or 2 years. These show a wide range of annual NEE between sites and between years of the same site (Aurela et al., 2004; Roulet et al., 2007; Nilsson et al., 2008; Lund et al., 2009; Sottocornola \& Kiely, 2010). In addition to NEE, the $\mathrm{CH}_{4}$ emissions (Granberg et al., 2001; Roulet et al., 2007; Nilsson et al., 2008) and the fluvial losses of $C$ as dissolved organic carbon (DOC) (Dawson et al., 2004; Roulet et al., 2007; Nilsson et al., 2008) in peatlands vary between sites and from year to year. The seasonal and interannual variation (IAV) of all C flux components reflects the strong influence and sensitivity to present 
climate conditions as well as site-specific characteristics (e.g., vegetation, chemical status and microform patterns). To our knowledge, only two studies have combined all $\mathrm{C}$ flux components with measurements at the same time and space with the aim to estimate the total annual C balance for a peatland (Roulet et al., 2007; Nilsson et al., 2008). In the longest known peatland C balance study, in Mer Bleue, an ombrothropic continental raised bog in Canada, Roulet et al. (2007) measured a mean annual $C$ balance of $-21.5 \pm 39.0 \mathrm{~g} \mathrm{~m}^{-2}$ during a 6 years time period (a negative sign is the micrometeorological convention indicating $C$ sequestered by the ecosystem). Multiannual measurements of $\mathrm{C}$ balances from individual peatland sites are important to elucidate the uncertainty about their current role in $\mathrm{C}$ sequestration. Furthermore, continuity of these measurements is essential if progress is to be made in modelling the peatland's C balance for future climate change scenarios.

The objectives of this study are to present the annual C balance for an Atlantic blanket bog over a 6 years period including the three main inputs and outputs to the ecosystem (NEE, $\mathrm{CH}_{4}$, and DOC) and to study their interannual and seasonal variability.

\section{Materials and methods}

\section{Site description}

The study site is located in an Atlantic blanket bog near Glencar in southwest Ireland $\left(51^{\circ} 55^{\prime} \mathrm{N}, 9^{\circ} 55^{\prime} \mathrm{W}\right.$, about $150 \mathrm{~m}$ above sea level). This peatland is typical of Atlantic blanket bogs in the maritime regions of northwestern Europe in terms of both vegetation and water chemistry (Sottocornola et al., 2009). The surface of the bog is a mosaic of microforms that differ in relative altitude, plant composition and water table depth. Four classes were distinguished: hummocks (6\%), high lawns (62\%), low lawns (21\%) and hollows (11\%) (Laine et al., 2006) with an elevation difference of $20-40 \mathrm{~cm}$ between the highest and lowest microform. The peat depth ranged from about $0.5 \mathrm{~m}$ (at the margins and on the steepest slopes) to over $5 \mathrm{~m}$ (Sottocornola et al., 2009; C. Lewis, personal communication).

A stream draining the peatland was monitored to measure the fluvial loss of DOC (Koehler et al., 2009). The stream has its boundaries inside the bog on the west, east and north and is delimited by a small country road on the south. The catchment area of the stream is approximately $74 \mathrm{ha}$; $85 \%$ of which is relatively intact bog (Sottocornola et al., 2009) and $15 \%$ is on a hill slope covered by patches of grassland and peaty soils.

The experimental arrangement consists of a micrometeorological tower equipped with meteorological sensors and an eddy-covariance (EC) system for $\mathrm{CO}_{2}$ flux measurements between the biosphere and the atmosphere. The small stream draining the peatland was monitored for flow and water chemistry. The meteorological and EC station was located in the central part of the peatland near the northeastern border of the stream's catchment while the stream monitoring system was located at the northern outfall of the catchment.

\section{Environmental measurements}

The meteorological station (established in 2002, Kiely et al., 2009) included a sensor for $Q_{\mathrm{PAR}}$, photosynthetically active radiation (PAR Lite; Kipp \& Zonen, Delft, the Netherlands), a shielded probe for air temperature measurements at $2 \mathrm{~m}$ height (HMP45C; Vaisala, Hilsinki, Finland), and probes for soil temperature recordings at different depths (107; Campbell Scientific, Loughborough, UK). Precipitation in the study site was measured with two tipping bucket rain gauges (an ARG100; Environmental Measurements Ltd., Sunderland, UK and an Obsermet OMC-200; Observator BV, Ridderkerk, The Netherlands) while water table level was measured with a pressure transducer (PCDR1830; Campbell Scientific).

Stream height was recorded every 30 min since January 2007 using a pressure transducer (1830 Series; Druck Ltd., Leicester, UK). Manual measurements of instantaneous discharge were carried out at a range of stream heights using an OTT current meter (OTT Messtechnik GmbH \& Co KG, Kempten, Germany). The manual discharge measurements were used to establish a rating curve [Eqn (1)], which converted the continuously recorded stream height to discharge:

$$
\begin{aligned}
& Q=0.6946 \times(\mathrm{SH}-0.08071)^{1.441}, \\
& r^{2}=0.9986, \mathrm{RMSE}=0.005,
\end{aligned}
$$

where $Q$ is discharge in $\mathrm{m}^{3} \mathrm{~s}^{-1}$ and $\mathrm{SH}$ stream height in $\mathrm{m}$. The total discharge was calculated by integrating the $30 \mathrm{~min}$ discharge data. Error analysis for $Q$ and drainage basin area was performed using the approach of Fraser et al. (2001). The discharge error was determined from the standard error of the rating curve $( \pm 0.005)$, such that minimum and maximum $Q$ were calculated using stages that ranged $\pm 0.005 \mathrm{~m}$ about the best-fit line. Furthermore, a drainage basin error of $5 \%$ was included (Fraser et al., 2001). The error of $Q$ was taken into account for the calculation of the measured DOC flux in 2007 and 2008 .

\section{Current $C$ flux measurements}

For the calculation of the annual $\mathrm{C}$ balance, the six calendar years between January 1, 2003 and December 31, 2008 were considered. A summary of the methods and time periods of measurements for $\mathrm{CO}_{2}, \mathrm{CH}_{4}$ and DOC fluxes are given in the following sections. Seasonal variation in the fluxes was investigated with the seasons defined as: winter (December-February), spring (March-May), summer (June-August), and autumn (September-November).

NEE. The EC technique was used to measure the net flux of $\mathrm{CO}_{2}$ at a height of $3.0 \mathrm{~m}$ above the high lawn vegetation (since September 2002, and to continue till at least 2011). The EC system consists of a 3-D sonic anemometer (Model 81000; R. M. Young Company, 
Traverse City, MI, USA) and an open-path $\mathrm{CO}_{2} / \mathrm{H}_{2} \mathrm{O}$ infrared gas analyser (LI-7500; LI-COR, Lincoln, NE, USA). Data were recorded at $10 \mathrm{~Hz}$ and those passing an automatical online quality check were Reynolds-averaged over $30 \mathrm{~min}$. The postfield data processing included a double rotation and air density variation corrections (Webb et al., 1980); filters were then established to discard bad fluxes separately for day and nighttime data sets (a threshold of incoming radiation of $10 \mathrm{~W} \mathrm{~m}^{-2}$ was used to distinguish day and nighttime fluxes). After the data processing, the amount of good remaining $\mathrm{CO}_{2}$ fluxes was $59 \%$ for the daytime and $26 \%$ for the nighttime on average over the 6 years. The under-representation of nighttime data prevalently occurred outside the growing season, when a large part of the $\mathrm{CO}_{2}$ fluxes were discarded because negative, likely due to the heating effect of the Licor-7500 (Burba et al., 2008), which anyway did not affect the reliability of the EC flux measurement and computation in Glencar (Sottocornola \& Kiely, 2010). The gaps arising in the time series were filled by nonlinear regression equations relating $\mathrm{CO}_{2}$ flux to either $Q_{\text {PAR }}$ or temperature for monthly to bimonthly periods. Details of the postfield processing and gap-filling procedures can be found in Sottocornola \& Kiely (2005) and Sottocornola \& Kiely (2010).

The uncertainty associated with annual estimates of NEE was computed as follows. A $20 \%$ random error was applied to each $30 \mathrm{~min}$ value of NEE and an annual error estimate was computed using propagation of errors (Morgenstern et al., 2004). The uncertainty due to the nonlinear relationships used for gap-filling was assessed through a bootstrap approach (Humphreys et al., 2005), so that each monthly to bimonthly period in every year was resampled with replacement and the nonlinear relationship was determined and used to gap-fill the original data set. This procedure was repeated 1000 times, the annual sums of NEE were calculated and their $95 \%$ confidence interval determined. In this paper the annual NEE values are the median of the 1000 repetitions.

Methane fluxes $\left(\mathrm{CH}_{4}\right)$. The closed chamber method was used to estimate the flux of $\mathrm{CH}_{4}$ from the peatland. Methane measurements conducted from August 2003 until September 2005 are described in Laine et al. (2007). Further $\mathrm{CH}_{4}$ chamber measurements were carried out at biweekly to monthly intervals during 2008. Owing to relatively mild winters with little frost it was possible to sample all the year round. Four replicate plots were sampled for each of the three microforms: hummock, high lawn and low lawn. Different to Laine et al. (2007) the hollows were further divided into hollows with a mud bottom, hollows covered by mosses only, by vascular plants without Menyanthes trifoliata or by vascular plants including $M$. trifoliata. Four replicates were sampled for each defined hollow type. As it was not possible to install collars at four of the hollow plots, the chamber size was reduced from $0.6 \times 0.6 \times 0.25$ to $0.3 \times 0.3 \times 0.3 \mathrm{~m}$ to use floating chambers. Except for the size, the remaining chamber features and additional measurements of soil temperature at different depths and water table depth for each plot were the same as in Laine et al. (2007). Accordingly the same nonlinear regression approach as in Laine et al. (2007) was used to reconstruct $\mathrm{CH}_{4}$ fluxes for the period 2003-2008:

$$
\mathrm{CH}_{4}=(c+d \times \mathrm{WTL})\left(\exp \left(b \times T_{\text {soil } 20 \mathrm{~cm}}\right)\right),
$$

where $b, c$ and $d$ are parameters, WTL is water table level and $T_{\text {soil }} 20 \mathrm{~cm}$ soil temperature at $20 \mathrm{~cm}$ depth. Equation (2) was parameterised for each sample plot separately based on the periodic chamber measurements between 2003 and 2005 and during 2008 and then used to estimate the $\mathrm{CH}_{4}$ flux for the whole period 2003-2008. If the linear function describing the relationship of WTL to $\mathrm{CH}_{4}$ flux did not increase the explanatory power of Eqn (2), it was replaced with a constant $a$. Four plots had to be taken out of the final flux calculation as the fit of the nonlinear regression was not satisfactory; nevertheless at least three replicates were available for each microform. For the $\mathrm{CH}_{4}$ flux integration, continuous $(30 \mathrm{~min})$ time series of $T_{\text {soil } 20 \mathrm{~cm}}$ and $W T L$ for each sample plot were reconstructed from the $T_{\text {soil } 20 \mathrm{~cm}}$ and $W T L$ continuously measured at the meteorological station. The annual $\mathrm{CH}_{4}$ flux was calculated through an up-scaling based on the known average distribution of the microforms around the EC tower (as defined by Laine et al., 2006).

The standard error of the average annual $\mathrm{CH}_{4}$ flux from each microform type was computed and weighted according to the microform distribution to estimate an error for the annual $\mathrm{CH}_{4}$ fluxes (Laine et al., 2007).

DOC. Continuous measurements (30 min interval) of DOC in the stream began in January 2007 using a spectroanalyser (spectro::lyser ${ }^{\mathrm{TM}}$, scan Messtechnik $\mathrm{GmbH}$, Vienna, Austria) (see Koehler et al., 2009). The DOC flux was computed as the product of DOC concentration and discharge. For the years 2003-2006, the measured stream height and DOC concentration were not available and were therefore modelled as follows. The monthly discharge was regressed against monthly precipitation (data 2007-2008):

$$
\begin{aligned}
& Q=\text { precip } \times 0.896+6.138, \\
& r^{2}=0.90, \text { RMSE }=35.7,
\end{aligned}
$$

where $Q$ is discharge and precip is the precipitation, both in $\mathrm{mm}$. The best relationship for DOC concentration was an s-shaped function of binned daily mean air 
temperature $\left(T_{\text {air }}\right.$ in $\left.{ }^{\circ} \mathrm{C}\right)$ and daily mean DOC concentration (DOC in $\mathrm{mg} \mathrm{L}^{-1}$ ) (data 2007-08, Fig. 1):

$$
\begin{aligned}
\mathrm{DOC} & =3.763+\frac{5.144}{1+\exp \left(-0.6888 \times T_{\text {air }}+7.387\right)}, \\
r^{2} & =0.92, \text { RMSE }=0.63 .
\end{aligned}
$$

An error estimate for Eqns (3) and (4) was computed as described for the relationship between stream height and discharge [Eqn (1)] (Fraser et al., 2001), resulting in a lower and upper estimate of the DOC flux for the period 2003-2006. To calculate the DOC flux for the period 2003-2006, the estimated daily DOC concentration was averaged over the month and multiplied by the estimated monthly discharge resulting in estimates of $12.6 \pm 3.2 \mathrm{~g} \mathrm{C} \mathrm{m}^{-2}$ for 2007 and $15.8 \pm 3.2 \mathrm{~g} \mathrm{C} \mathrm{m}^{-2}$ for 2008, compared with our measured values of $11.9 \pm 1.2$ and $15.0 \pm 1.3 \mathrm{~g} \mathrm{C} \mathrm{m}^{-2}$ for 2007 and 2008, respectively.

Additionally, DOC concentration in precipitation was measured over a 1-year period $(n=7)$ with three replicates each time using a funnel with an attached bottle. The bottles were left out in the field for up to 3 days during a rainy period and were analysed for DOC concentration thereafter as described below. The product of the mean DOC concentration over the 1year period and the annual amount of precipitation was used to estimate the DOC input in precipitation for each year. For the stream water, a 24-bottle auto-sampler (6712 portable sampler; Teledyne Isco Inc., Lincoln,
NE, USA) was used every 6-8 weeks and the samples were analysed for DOC and total organic C using a TOC-V cpH (SHIMADZU Scientific Instruments, Columbia, MD, USA). The flux of particulate organic carbon (POC), which is the difference between total and DOC was estimated using the average percentage of POC calculated from the bottle auto-sampler results.

\section{Bulk density}

Samples for bulk density were taken using a peat core sampler (Eijkenkamp Agrisearch Equipment BV, Giesbeek, the Netherlands) at four different locations in the bog, at half-meter intervals, three replicates at each depth. The peat samples were oven-dried to a constant mass at $55{ }^{\circ} \mathrm{C}$ and weighted; bulk density was calculated by dividing the dry mass by the fresh volume.

\section{Results}

\section{Current environmental conditions}

The study of the 6 years measurements showed a wide range of environmental conditions. We ranked the seasonal temperature and precipitation from 2003 to 2008 from the nearest synoptic weather station (Valentia, located ca. $30 \mathrm{~km}$ West of Glencar, http://www. meteireann.ie/climate/valentia.asp) within their past long-term record (1940-2008) as done by Roulet et al.

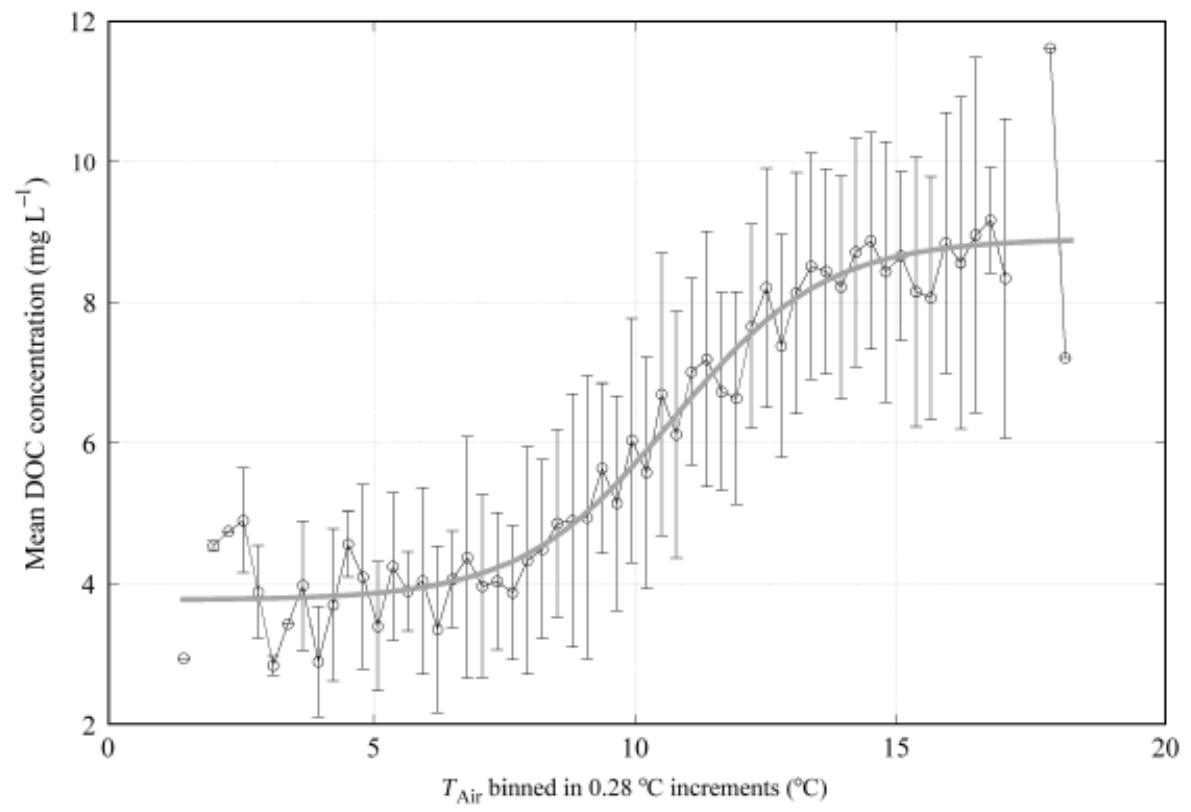

Fig. 1 S-shaped relationship of binned mean daily air temperature $\left(T_{\text {air }}\right)$ and corresponding mean daily dissolved organic carbon (DOC) concentration. 
(2007) (Fig. 2). Only two out of 23 seasons experienced no significant temperature and/or precipitation anomaly, i.e., not in the upper or lower quartile (winter 2005/ 2006 and summer 2004). On the contrary seven seasons experienced both temperature and precipitation anomalies (drier/wetter and warmer/cooler). In total, eight seasons received significantly higher precipitation with spring being the season with most precipitation anomalies (Fig. 2). Lower precipitation was observed only for four seasons. In general, precipitation at the Glencar peatland showed a large IAV over the 6 years observation period from $2235 \mathrm{~mm}$ in 2007 up to $2952 \mathrm{~mm}$ in 2006 (which corresponds to a 32\% increase over the driest year) as well as a high inter-seasonal variation (Fig. 3c). The average number of wet days (i.e., $>1 \mathrm{~mm} \mathrm{day}^{-1}$ ) was 209. Temperature showed an even higher number of anomalies than precipitation with $65 \%$ of the study period (thus 15 seasons) experiencing temperatures in the top quartile (Fig. 2). Only one single season was colder than normal. The average annual air temperature over the period 2003-2008 was $10.6 \pm 0.2$ $( \pm 1 \mathrm{SD}){ }^{\circ} \mathrm{C}$ with a mean average air temperature from May to October of $13.3 \pm 0.4{ }^{\circ} \mathrm{C}$ and from November to April of $7.8 \pm 0.4{ }^{\circ} \mathrm{C}$. Daytime $Q_{\text {PAR }}$ showed low IAV with slightly higher standard deviation during the summer than the winter time (Fig. 3a). During 20032008 the water level fluctuations ranged between $2 \mathrm{~cm}$ above and $17 \mathrm{~cm}$ below the low lawn surface with low standard deviation during the winter and higher standard deviation during the summer time (Fig. 3d) resulting in a mean annual difference over the 6 years of $3 \mathrm{~cm}$.

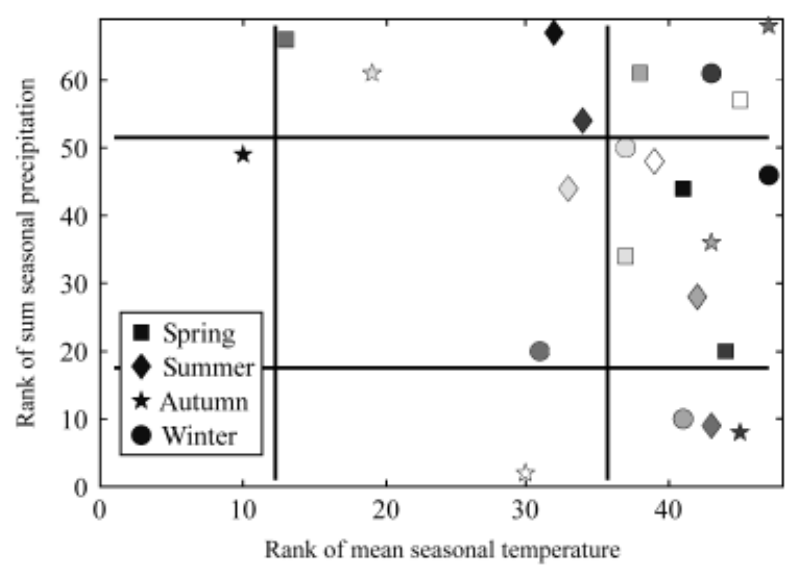

Fig. 2 Rank of the seasonal temperature and precipitation of the period 2003-2008, relative to the rank for the past 47 years for temperature and past 68 years for precipitation. 2003 is in white and the colour shading is getting darker for each following year until 2008 is shown in black.

\section{Annual NECB}

The measured annual cumulative NEE ranged from a minimum uptake of $12.5 \mathrm{gC}-\mathrm{CO}_{2} \mathrm{~m}^{-2}$ in 2006 to a maximum uptake of $84.0 \mathrm{gC}-\mathrm{CO}_{2} \mathrm{~m}^{-2}$ in 2005 with a 6 years mean annual cumulative NEE of $-47.8 \pm 30.0$ ( $\pm 1 \mathrm{SD}$ ) $\mathrm{g} \mathrm{C}^{-} \mathrm{CO}_{2} \mathrm{~m}^{-2} \mathrm{yr}^{-1}$ (Fig. 4, Tables 1 and 2). The uncertainty associated with each estimate of annual NEE is less than $0.8 \mathrm{gC}-\mathrm{CO}_{2} \mathrm{~m}^{-2} \mathrm{yr}^{-1}$ for random errors and the error associated with individual $\mathrm{C}$ measurements on the gap-filling technique ranged between \pm 2 and $\pm 5 \mathrm{gC}^{-} \mathrm{CO}_{2} \mathrm{~m}^{-2} \mathrm{yr}^{-1}$ within the 6 years (Table 1). On a seasonal basis, winter NEE was always positive, i.e., a loss of $\mathrm{C}$ to the atmosphere ranging from 13 to $26 \mathrm{gC}^{-} \mathrm{CO}_{2} \mathrm{~m}^{-2}$ while the summer showed always an uptake of $\mathrm{C}$ in the order of $42-88 \mathrm{~g} \mathrm{C}-\mathrm{CO}_{2} \mathrm{~m}^{-2}$ (Fig. 5a). Spring as well as autumn showed an average close to zero while varying between uptake and loss of $\mathrm{C}$ between the years (Fig. 5a). The largest variation was observed for spring and summer (Fig. 5a).

Methane flux from the peatland differed between microform type (Laine et al., 2007). Integrating the flux from all microforms according to their spatial distribution within the EC footprint, the annual emission of $\mathrm{CH}_{4}$ ranged from 3.6 to $4.6 \mathrm{gC}-\mathrm{CH}_{4} \mathrm{~m}^{-2} \mathrm{yr}^{-1}$ with a 6

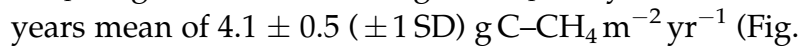
4 , Tables 1 and 2). The standard errors of the average annual $\mathrm{CH}_{4}$ flux varied between years and microforms (Table 1). Flux from hollows including M. trifoliata had the highest variation between replicate plots (6 years average $\pm 2.6 \mathrm{gC}^{-} \mathrm{CH}_{4} \mathrm{~m}^{-2} \mathrm{yr}^{-1}$ ) and hollows with moss cover the lowest (6 years average $\pm 0.6 \mathrm{gC}-$ $\left.\mathrm{CH}_{4} \mathrm{~m}^{-2} \mathrm{yr}^{-1}\right)$. The weighted error across all microforms ranged from 1.6 to $2.0 \mathrm{gC}^{-} \mathrm{CH}_{4} \mathrm{~m}^{-2} \mathrm{yr}^{-1}$ over the 6 years (Table 1). On a seasonal basis the flux increased in the order winter $<$ spring $<$ autumn $<$ summer and with increased flux also the variation among the 6 years increased (Fig. 5b).

Discharge from the catchment of the peatland stream always exceeded $1900 \mathrm{~mm} \mathrm{yr}^{-1}$. For the 2 years of DOC measurements (2007 and 2008), the average DOC concentration was $6.5 \pm 2.0( \pm 1 \mathrm{SD})$ and $6.1 \pm 2.7 \mathrm{mg} \mathrm{L}^{-1}$ resulting in an annual loss of $C$ as DOC of 11.9 and $15.0 \mathrm{~g} \mathrm{C} \mathrm{m}^{-2}$ in 2007 and 2008, respectively (Fig. 4). The annual error associated with the discharge measurements and the basin area were \pm 1.2 and $\pm 1.3 \mathrm{~g} \mathrm{C} \mathrm{m}^{-2}$ for 2007 and 2008, respectively (Table 1). For the years 2003-2006, the modelled DOC flux [Eqns (3) and (4)] and error estimates ranged between $13.1 \pm 3.1$ and $16.5 \pm 3.2 \mathrm{~g} \mathrm{C} \mathrm{m}^{-2}$ (Fig. 4, Table 1). This results in an annual average DOC flux estimate of $14.0 \pm 1.6( \pm 1$ SD) $\mathrm{g} \mathrm{C} \mathrm{m}^{-2}$ (Fig. 4, Table 2). On a seasonal basis the DOC flux did not show a clear pattern but for the 6 years average it increased in the order spring $<$ summer 
(a)
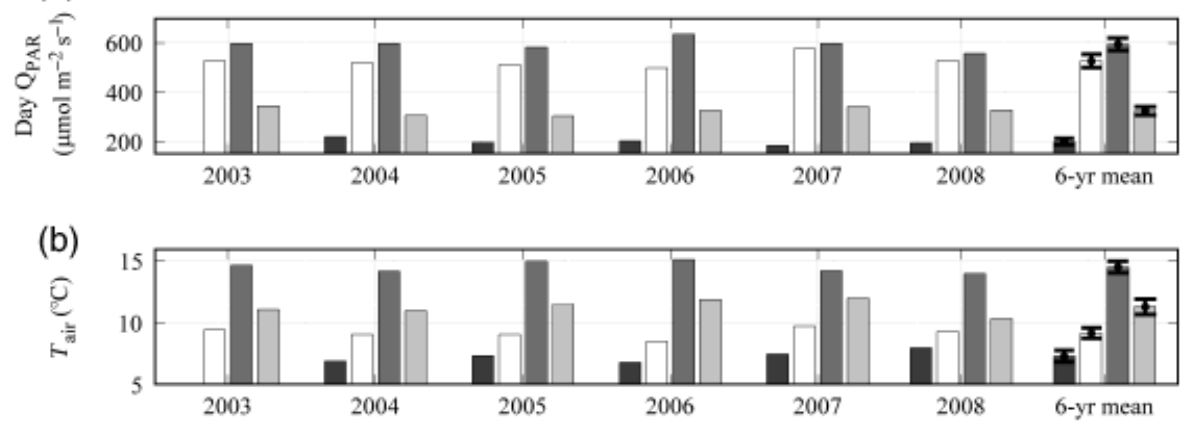

(c)

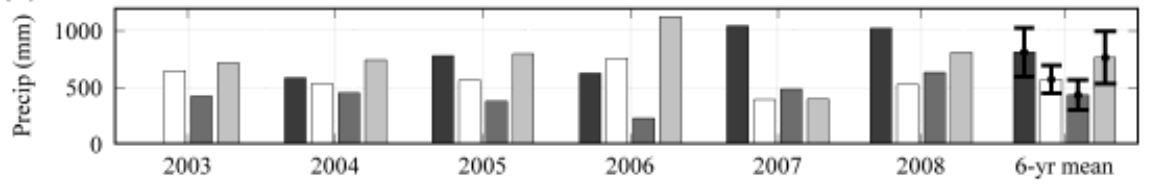

(d)

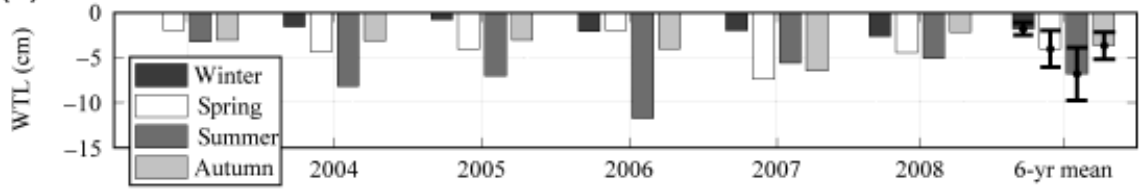

Fig. 3 Seasonal variation for the years 2003-2008 and average over the 6 years for daytime $Q_{\mathrm{PAR}}$ (a), air temperature (b), precipitation (c) and water table level (d).

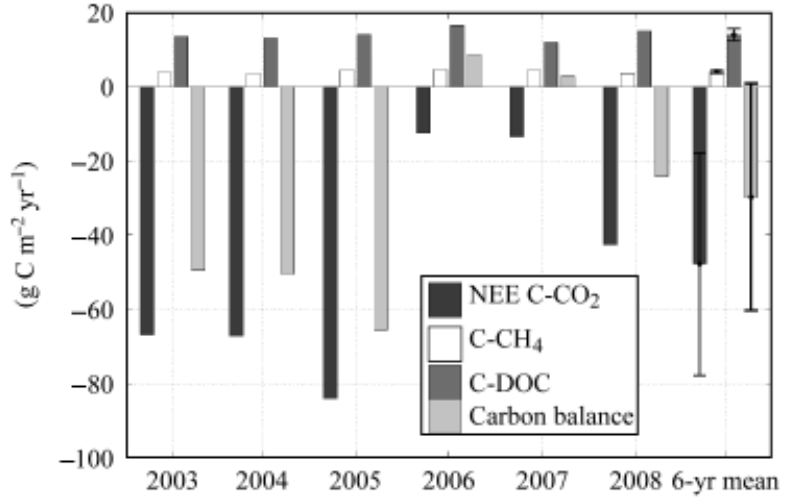

Fig. 4 Sums of the annual carbon balance components for 2003-2008 and their 6 years mean and standard deviation. The flux of dissolved organic carbon (DOC) only includes the loss of DOC in the stream.

$<$ winter $<$ autumn with the highest interseasonal variation in autumn and similar ranges for the other three seasons (Fig. 5c). On average, the concentration of POC in the stream was $6.5 \%$ of the total organic $C$, which equates to a loss of POC from the catchment of about $1.0 \mathrm{~g} \mathrm{C} \mathrm{m}^{-2} \mathrm{yr}^{-1}$. The peatland received carbon as DOC through precipitation with a mean concentration of $0.7 \mathrm{mg} \mathrm{L}^{-1}$ adding between 1.7 and $2.2 \mathrm{gC} \mathrm{m}^{-2} \mathrm{yr}^{-1}$ (average $1.9 \mathrm{~g} \mathrm{C} \mathrm{m}^{-2} \mathrm{yr}^{-1}$ ) in the years 2003-2008. In the following $\mathrm{C}$ balance discussion, the input of $\mathrm{C}$ through rain and the loss through POC were not taken into account as they approximately cancel each other out.

Combining the annual import and export of $\mathrm{C}$ for the Glencar bog resulted in a mean 6 years $C$ balance of $-29.7 \pm 30.6( \pm 1 \mathrm{SD}) \mathrm{g} \mathrm{m}^{-2} \mathrm{yr}^{-1}$ with NEE being the largest and most variable component of the $C$ balance (Fig. 4, Tables 1 and 2). During the 6 years NEE was always negative (Fig. 4, Table 1), i.e., a net uptake of $\mathrm{CO}_{2}$. The calculation of the total $\mathrm{C}$ balance $\left(\mathrm{C}-\mathrm{CO}_{2}+\right.$ $\left.\mathrm{C}-\mathrm{DOC}+\mathrm{C}-\mathrm{CH}_{4}\right)$ showed that the 2 years 2006 and 2007 were small $C$ sources while the remaining 4 years were sinks for $\mathrm{C}$ (Fig. 4, Tables 1 and 2). On average, the $\mathrm{C}$ loss as $\mathrm{CH}_{4}$ and DOC accounted for about $9 \%$ and $29 \%$ of the mean NEE, respectively. As done by Roulet et al. (2007) we combined all the seasons with the lowest and the highest NEE, $\mathrm{CH}_{4}$ and DOC to bracket the potential maximum and minimum carbon balance between +15 and $-85 \mathrm{~g} \mathrm{~m}^{-2} \mathrm{yr}^{-1}$. This estimate might overestimate the range of the $\mathrm{C}$ balance since this approach improperly considers that the distribution of the three fluxes is independent.

Bulk density samples from Glencar did not show any significant variation with depth and had an average 
Table 1 NEE, $\mathrm{CH}_{4}$, DOC and C balance for Glencar for the years 2003-2008 based on measurements and predictions

\begin{tabular}{|c|c|c|c|c|}
\hline & $\mathrm{NEE}\left(\mathrm{gC}-\mathrm{CO}_{2} \mathrm{~m}^{-2} \mathrm{yr}^{-1}\right)$ & $\mathrm{CH}_{4}\left(\mathrm{gC}-\mathrm{CH}_{4} \mathrm{~m}^{-2} \mathrm{yr}^{-1}\right)$ & DOC $\left(\mathrm{gCm}^{-2} \mathrm{yr}^{-1}\right)$ & $\mathrm{C}$ balance $\left(\mathrm{gC} \mathrm{m}^{-2} \mathrm{yr}^{-1}\right)$ \\
\hline 2003 & $-66.8 \pm 5.2$ & $3.8 \pm 1.6$ & $13.5 \pm 3.2$ & $-49.6 \pm 6.3$ \\
\hline 2004 & $-67.2 \pm 3.0$ & $3.6 \pm 1.6$ & $13.1 \pm 3.1$ & $-50.5 \pm 4.6$ \\
\hline 2005 & $-84.0 \pm 4.8$ & $4.5 \pm 1.9$ & $13.9 \pm 3.2$ & $-65.6 \pm 6.1$ \\
\hline 2006 & $-12.5 \pm 3.4$ & $4.6 \pm 2.0$ & $16.5 \pm 3.2$ & $8.6 \pm 5.1$ \\
\hline 2007 & $-13.5 \pm 2.3$ & $4.2 \pm 1.9$ & $11.9 \pm 1.2$ & $2.8 \pm 3.2$ \\
\hline 2008 & $-42.7 \pm 4.7$ & $3.6 \pm 1.6$ & $15.0 \pm 1.3$ & $-24.1 \pm 5.1$ \\
\hline
\end{tabular}

The given error estimate for each flux is calculated as described in 'Materials and methods'.

$\mathrm{NEE}$, net ecosystem exchange; $\mathrm{CH}_{4}$, methane; DOC, dissolved organic carbon.

Table 2 NEE, $\mathrm{CH}_{4}$ and DOC (TOC for Degerö Stormyr) ( $\pm 1 \mathrm{SD}$ ) for Glencar, Mer Bleue and Degerö Stormyr and their estimated C balance including the three fluxes

\begin{tabular}{|c|c|c|c|}
\hline & Glencar (Ireland) & Mer Bleue (Canada) & Degerö Stormyr (Sweden) \\
\hline 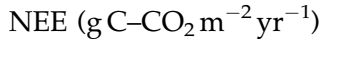 & $-47.8 \pm 30.0$ & $-40.2 \pm 40.5$ & $\begin{array}{l}-51.5 \pm 4.9 \\
(5 \text { years }-53.6 \pm 5.6)\end{array}$ \\
\hline $\mathrm{CH}_{4}\left(\mathrm{gC}-\mathrm{CH}_{4} \mathrm{~m}^{-2} \mathrm{yr}^{-1}\right)$ & $4.1 \pm 0.5$ & $3.7 \pm 0.5$ & $11.5 \pm 4.9$ \\
\hline DOC (TOC) $\left(\mathrm{gC} \mathrm{m}^{-2} \mathrm{yr}^{-1}\right)$ & $14.0 \pm 1.6$ & $14.9 \pm 3.1$ & $13.0 \pm 1.5$ \\
\hline $\mathrm{C}$ balance $\left(\mathrm{gC} \mathrm{m}^{-2} \mathrm{yr}^{-1}\right)$ & $-29.7 \pm 30.6$ & $-21.5 \pm 39.0$ & $-27.1 \pm 7.0$ \\
\hline
\end{tabular}

NEE, net ecosystem exchange; $\mathrm{CH}_{4}$, methane; DOC, dissolved organic carbon; TOC, total organic carbon.

value of $0.045 \mathrm{~g} \mathrm{~cm}^{-3}$ (C. Lewis, unpublished results). Using this bulk density value and assuming that soil organic carbon (SOC) in organic matter is about $50 \%$, a rough estimate of the peat height growth at the surface can be calculated. The 6 years average carbon balance was converted into a height growth rate of $1.3 \mathrm{~mm} \mathrm{yr}^{-1}$ ranging from a loss of peat of $0.4 \mathrm{~mm} \mathrm{yr}^{-1}$ (2006) to a growth of $2.9 \mathrm{~mm} \mathrm{yr}^{-1}$ (2005).

\section{Discussion}

The Glencar blanket bog showed an average annual C accumulation rate of $-29.7 \mathrm{~g} \mathrm{C} \mathrm{m}^{-2} \mathrm{yr}^{-1}$ with a large IAV ranging from a source of 8.6 to a sink of $-65.6 \mathrm{~g} \mathrm{C} \mathrm{m}^{-2} \mathrm{yr}^{-1}$ within the 6 years period (Fig. 4, Table 1). Precipitation and temperature exhibited a wide range as well but were biased towards wetter and warmer conditions compared with the period 19612000 , raising the question on the representativeness of the measured time period as mean $C$ accumulation rate of the long-term climatic conditions. The sum of the $\mathrm{CH}_{4}$ and DOC flux was greater than NEE in 2 of the 6 years, confirming that not including the $\mathrm{CH}_{4}$ and DOC fluxes can largely overestimate the $\mathrm{C}$ sink status of a peatland ecosystem. One of the 6 years (2006) had a fluvial loss of DOC even greater than NEE.

Sottocornola \& Kiely (2010) presented a detailed analysis of the variation in NEE related to environmental conditions in Glencar for the 5 years October 2002 to September 2007. They found that the IAV of the annual NEE correlated positively with an earlier onset of the growing season but not with any other hydro-meteorological parameter. On a seasonal basis, the $\mathrm{CO}_{2}$ uptake showed a preference for wet conditions in autumn and winter and for intermediate environmental conditions (not too wet, not too dry; not too cold not too hot) during the summer (2005, Figs 3 and 5a).

The flux of $\mathrm{CH}_{4}$ in Glencar seemed to be more strongly related to temperature than to changes in water table level. The inclusion of the water table level in the nonlinear regression model [Eqn (2)] increased the explanatory power only for the wettest plots. Hence, spring, summer and autumn with the highest (lowest) $\mathrm{CH}_{4}$ flux corresponded to the years with the warmest (coldest) seasons (Figs $3 \mathrm{~b}$ and $5 \mathrm{~b}$ ). Winter $\mathrm{CH}_{4}$ flux only showed a very small IAV due to its very low flux.

In Glencar, the highest monthly DOC flux did not occur at the same time as the highest DOC concentrations in the stream, which occurred during the summer time (Koehler et al., 2009). While in Glencar the DOC concentration showed a strong relationship to temperature (Fig. 1), the DOC flux is controlled by the discharge (Koehler et al., 2009). Therefore, no clear seasonal pattern can be observed for the DOC flux, but the highest flux corresponded to the season with the highest precipitation (autumn 2006) (Figs 3c and 5c).

To our knowledge, there are only two comparable studies presenting a multiannual $C$ balance of a peatland ecosystem: Roulet et al. (2007) examined 6 years C balance of the Mer Bleue peatland, an ombrotrophic continental raised bog in southeast Canada, while Nilsson et al. (2008) presented 2 years $C$ balance from the 

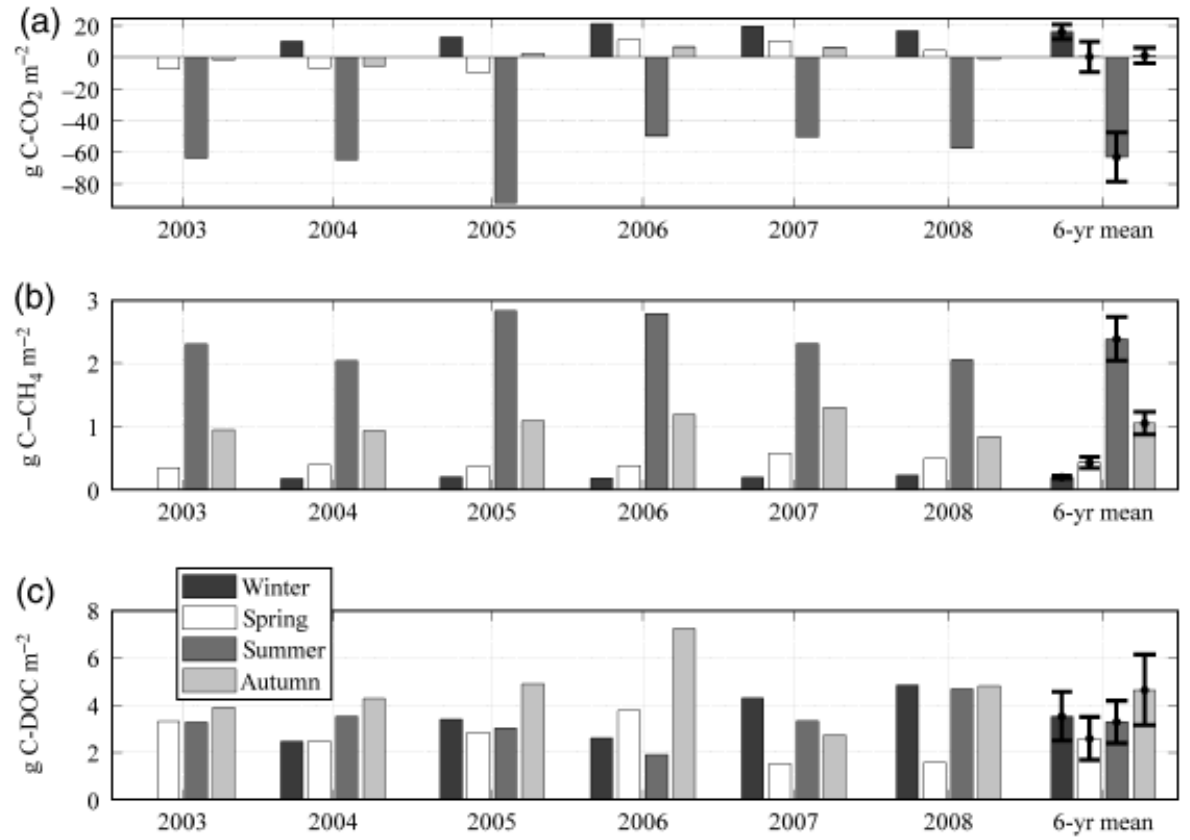

Fig. 5 Seasonal variation and average over the 6 years (2003-2008) of (a) net ecosystem exchange (NEE), which was entirely based on measurements; (b) $\mathrm{CH}_{4}$ flux, which was estimated from periodic chamber measurements in 2003-2005 and in 2008; and (c) DOC flux, which was assessed based on measurements in 2007 and 2008.

Degerö Stormyr peatland, a minerogenic oligotrophic mire in northern Sweden. Despite differences in plant functional types, hydrology (runoff of about 400 and $450 \mathrm{~mm} \mathrm{yr}^{-1}$ for Mer Bleue and Degerö Stormyr, compared with $>1900 \mathrm{~mm} \mathrm{yr}^{-1}$ in Glencar), chemical character and climatic conditions (continental and maritime settings), each having an influence on the single $C$ flux components, the average $\mathrm{C}$ balance of the three peatlands showed very similar results (Table 2). Glencar and Mer Bleue's $C$ balance showed a large IAV of similar order ranging from a sink to a source of $C$, while Degerö Stormyr's $C$ balance exhibited a low IAV and was a sink in each year of measurement (Table 2). Also the partitioning of the single fluxes and their IAV was very similar for Glencar and Mer Bleue but somewhat different for Degerö Stormyr (Table 2).

For all three sites, NEE was the main component of the $C$ balance for most years. The average annual NEEs were very similar, with Glencar and Mer Bleue exhibiting a much larger IAV than Degerö Stormyr (5 years NEE record, Nilsson et al., 2008; Sagerfors et al., 2008) (Table 2). Even though similar on an annual scale, seasonally Glencar and Degerö Stormyr showed a lower $\mathrm{C}$ loss during the winter and a smaller uptake during the growing season than Mer Bleue. Although there are multiple factors influencing NEE, the lower summer uptake in Glencar might be mainly attributed to a lower leaf area index (LAI) compared with Mer Bleue (Glen- car: $0.6 \mathrm{~m}^{2} \mathrm{~m}^{-2}$, Mer Bleue: $1.3 \mathrm{~m}^{2} \mathrm{~m}^{-2}$ ) while the lower loss in winter in Glencar is likely due to some uptake by mosses and evergreen vascular plants, since winters are mild and often suitable for photosynthesis (Sottocornola \& Kiely, 2010). The authors are not aware of LAI measurements for Degerö Stormyr. The importance of LAI was recently indicated in a NEE comparative study including 12 wetland sites across Europe and Northern America that found high $\mathrm{CO}_{2}$ uptake at sites with high LAI (Lund et al., 2009).

The flux and IAV of $\mathrm{CH}_{4}$ are larger in Degerö Stormyr compared with Glencar and Mer Bleue where they showed similar values (Table 2). The low $\mathrm{CH}_{4}$ flux in Mer Bleue is likely due to the dryness of the site [water table between 20 and $70 \mathrm{~cm}$ below the surface (Roulet et al., 2007)], compared with Glencar and Degerö Stormyr [water tables ranging between the surface to about 15 and $20 \mathrm{~cm}$ below the surface, respectively (Fig. 3) (Nilsson et al., 2008)]. Even so, the $\mathrm{CH}_{4}$ flux in Glencar is surprisingly only slightly higher than in Mer Bleue considering Glencar's high water table level, large proportion of sedges, higher $\mathrm{pH}$ (Glencar: $4.5>$ Degerö Stormyr: $4>$ Mer Bleue: 3.9) and no extreme soil sulphate concentration $\left(0.52-3.81 \mathrm{mg} \mathrm{L}^{-1}\right)$ compared with measurements in other peatlands in Ireland, the United Kingdom and Canada (1.9-9.6 $\mathrm{mg} \mathrm{L}^{-1}$ ) (WindMulder et al., 1996; Adamson et al., 2001; Proctor, 2006). These factors are all in favour of $\mathrm{CH}_{4}$ flux. The higher 
$\mathrm{CH}_{4}$ flux in Degerö Stormyr compared with Glencar might depend on Degerö Stormyr being dominated by lawn and carpet plant communities, microforms that were responsible for the highest efflux in Glencar (see also Laine et al., 2007). Besides, it has to be noted that the used technique might introduce possible bias in the comparison. All three sites used the chamber technique measuring fluxes at the plot (covering $<1 \mathrm{~m}^{2}$ ) and not ecosystem scale with time intervals being at best weekly and lacking diurnal variations. Furthermore different annual flux calculation models (Glencar, nonlinear regression; Mer Bleue and Degerö Stormyr, linear interpolation) and winter flux estimations were used (based on measurements in Glencar, zeroed in Mer Bleue, considered 20\% of annual flux in Degerö Stormyr). Moreover, the $\mathrm{CH}_{4}$ flux might be underestimated as ebullition is possible to occur which is not well captured with chambers (Christensen et al., 2003).

The annual flux of DOC is similar in the three sites though revealing major differences when investigating the combination of concentration and discharge. In Glencar, the mean annual DOC concentration is very low (6.3 $\mathrm{mg} \mathrm{L}^{-1}$, with DOC being about $93.5 \%$ of TOC) compared with Mer Bleue $\left(47.5 \mathrm{mg} \mathrm{L}^{-1}\right)$ and Degerö Stormyr (TOC concentration of $27.8 \mathrm{mg} \mathrm{L}^{-1}$ ). The low mean and small absolute range of DOC concentration in Glencar (Koehler et al., 2009) together with the high discharge ( $>1900 \mathrm{~mm} \mathrm{yr}^{-1}$ ) supports the suggestion that Glencar does not accumulate DOC in the soil as it is continuously flushed due to frequent rain events (even in the summer). For Degerö Stormyr and Mer Bleue, a build up of DOC in the soil may occur during the summer time due to extended dry periods resulting in a flushing of DOC after rain events in late summer and autumn so that storage of DOC varies over the year more considerably than in Glencar. Despite these different patterns, the annual DOC exports are similar in the three sites. In Glencar frequent heavy rains are accompanied with low DOC concentrations resulting in high DOC flux throughout the year, whereas in Mer Bleue and Degerö Stormyr the DOC concentrations are higher and the discharge lower on an annual basis and the annual $\mathrm{C}$ export results from episodes with high flow rates, most importantly the spring snow melt and the late summer and autumn intense rains (Roulet et al., 2007; Nilsson et al., 2008).

While the degassing of $\mathrm{CH}_{4}$ from the stream was found to be negligible (Billett et al., 2004; Dawson et al., 2004; Nilsson et al., 2008), both Glencar and Mer Bleue C balances lack the inclusion of the fluvial loss of inorganic $\mathrm{C}$, which was estimated to account for up to $7 \%-$ $31 \%$ of the total stream C export (Dawson et al., 2001; Billett et al., 2004; Nilsson et al., 2008). The use of this estimate for the loss of inorganic carbon would result in an additional loss of $\mathrm{C}$ for Glencar of 1.0$7.4 \mathrm{~g} \mathrm{C} \mathrm{m}^{-2} \mathrm{yr}^{-1}$ considering the lowest and highest annual DOC flux.

For Glencar, the average annual C balance for the 6 years was converted into an approximate growth rate of the peatland surface of $1.3 \mathrm{~mm} \mathrm{yr}^{-1}$ using bulk density measurements of $0.045 \mathrm{~g} \mathrm{~cm}^{-3}$. This value can not be directly compared with peat core studies of peat accumulation rates such as those over the past 400 years of $0.4 \mathrm{~mm} \mathrm{yr}^{-1}$ for the Mer Bleue bog (Roulet et al., 2007). Turunen et al. (2004) gives an average bulk density for 23 Canadian peatlands, including Mer Bleue, of 0.042 and $0.051 \mathrm{~g} \mathrm{~cm}^{-3}$ for hummocks and hollows, respectively, which would convert the average $C$ balance of Mer Bleue to a peat height growth of $0.8-1.0 \mathrm{~mm} \mathrm{yr}^{-1}$.

Summarizing, Glencar, Mer Bleue and Degerö Stormyr showed similar average $C$ balances with NEE being the main component for most of the years. Despite differences in peatland types, climatic and geographic location, most NEE studies report multiple year averages between 20 and $60 \mathrm{~g} \mathrm{C} \mathrm{m}^{-2} \mathrm{yr}^{-1}$ (Limpens et al., 2008) even if single years can vary largely as observed for Glencar and Mer Bleue. An important factor controlling the rate of carbon sequestration was found to be the peatland surface structure (Belyea \& Malmer, 2004). Eppinga et al. (2009a) suggested that different combinations of structuring mechanisms (peat accumulation, water ponding and nutrient accumulation) lead to the development of similar peatland surface patterns, which could explain the development of different peatland types into similar stable structures (Eppinga et al., 2009b). It has been argued that these similar structures might then exert a form of top-down control on peatland development in which large scale features (i.e., peatland size and shape) may constrain processes operating at a smaller scale (as acrotelm transmissivity, peat formation rate) leading to similar self-regulating processes (Belyea \& Baird, 2006). This might determine comparable peat accumulation rates in different peatland types as observed for Glencar, Mer Bleue and Degerö Stormyr.

\section{Conclusions}

In this paper, we present the results of a multiannual $\mathrm{C}$ balance study for the Glencar Atlantic blanket bog in County Kerry, southwest Ireland. We showed that NEE is not the only important component of the peatland $\mathrm{C}$ balance but that also the $\mathrm{CH}_{4}$ flux and stream water DOC flux are crucial components. NEE accounts for about $73 \%$ of the average $\mathrm{C}$ balance, while the $\mathrm{CH}_{4}$ flux and stream water DOC flux contribute with about $6 \%$ and $21 \%$, respectively. However, for two of the 6 years, the sum of the $\mathrm{CH}_{4}$ and DOC flux exceeded the NEE, 
making the site a source of carbon. NEE had a significant IAV while both the $\mathrm{CH}_{4}$ flux and stream water DOC flux showed low IAV. Therefore, the annual behaviour of NEE is the most important component determining the bog's annual $C$ status. The existence of similar self-regulating processes in peatlands was suggested in the literature to be a possible mechanism determining comparable peat accumulation rates in different peatland types as observed for Glencar, Mer Bleue and Degerö Stormyr. For further investigation of these processes and an understanding of the impact of the climate change on peatland ecosystems, it is recommended to continue the current $\mathrm{C}$ balance studies and to extend the measurements of the total $\mathrm{C}$ balance to other peatland sites.

\section{Acknowledgements}

This study was funded by the ERTDI Programme 2000-2006, financed by the Irish Government under the National Development Plan and administered on behalf of the Department of Environment and Local Government by the Environmental Protection Agency (CELTICFLUX 2001-CC-C2-M1). AK was funded by Environmental Protection Agency PhD fellowship (Grant code 2006 PhD AQ-4). We thank Caitriona Douglas of NPWS and Coillte Teoranta for permission to use the study site. We acknowledge in particular the earlier work of Dr. Anna Laine and her PhD work and papers from the same site and Dr. Paul Leahy for its useful discussion. We wish to acknowledge the assistance of Dr. Xie Quishi of the Aquatic Services Unit of University College Cork in the water quality analyses, Ciaran Lewis for the bulk density measurements and Adrian Birkby, Kilian Murphy and Nelius Foley for maintaining the instrumentations and support with the field work. We thank the reviewers for their useful comments and suggestions.

\section{References}

Adamson JK, Scott WA, Rowland AP, Beard GR (2001) Ionic concentration in a blanket peat bog in northern England and correlations with deposition and climate variables. European Journal of Soil Science, 52, 69-79.

Aurela M, Laurila T, Tuovinen J-P (2004) The timing of snow melt controls the annual $\mathrm{CO}_{2}$ balance in a subarctic fen. Geophysical Research Letters, 31, L16119, doi: 10.1029/ 2004GL020315.

Belyea LR, Baird AJ (2006) Beyond "The Limits of Peat Bog Growth": cross-scale feedback in peatland development. Ecological Monographs, 76, 299-322.

Belyea LR, Malmer N (2004) Carbon sequestration in peatland: patterns and mechanisms of response to climate change. Global Change Biology, 10, 1043-1052.

Billett MF, Palmer SM, Hope D et al. (2004) Linking land-atmosphere-stream carbon fluxes in a lowland peatland system. Global Biogeochemical Cycles, 18, GB1024, doi: 10.1029/2003GB002058.

Burba GG, McDermitt DK, Grelle A, Anderson DJ, Liukang XU (2008) Addressing the influence of instrument surface heat exchange on the measurements of $\mathrm{CO}_{2}$ flux from open-path gas analyzers. Global Change Biology, 14, 1854-1876.

Chapin FS III, Woodwell GM, Randerson JT et al. (2006) Reconciling carbon-cycle concepts, terminology, and methods. Ecosystems, 9, 1041-1050.

Christensen TR, Panicov N, Masterpanov $\mathrm{M}$ et al. (2003) Biotic control on $\mathrm{CO}_{2}$ and $\mathrm{CH}_{4}$ exchange in wetlands - a closed ecosystem study. Biogeochemistry, 64, 337-354.

Dawson JJC, Bakewell C, Billett MF (2001) Is in-stream processing an important control on spatial changes in carbon fluxes in headwater catchments? The Science of The Total Environment, 265, 153-167.
Dawson JJC, Billett MF, Hope D, Palmer SM, Deacon CM (2004) Sources and sinks of aquatic carbon in a peatland stream continuum. Biogeochemistry, 70, 71-92.

Eaton JM, McGoff NM, Byrne KA, Leahy P, Kiely G (2008) Land cover change and soil organic carbon stocks in the Republic of Ireland 1851-2000. Climatic Change, 91, 317334

Eppinga MB, de Ruiter PC, Wassen MJ, Rietkerk M (2009a) Nutrients and hydrology indicate the driving mechanisms of peatland surface patterning. The American Naturalist, 173, 803-818.

Eppinga MB, Rietkerk M, Wassen MJ, de Ruiter PC (2009b) Linking habitat modification to catastrophic shifts and vegetation patterns in bogs. Plant Ecology, 200, 53-68.

Fraser CJD, Roulet NT, Moore TR (2001) Hydrology and dissolved organic carbon biogeochemistry in an ombrotrophic bog. Hydrological Processes, 15, 3151-3166.

Gorham E (1991) Northern peatlands: role in the carbon cycle and probable responses to climate warming. Ecological Applications, 1, 182-195.

Granberg G, Ottosson-Lofvenius M, Grip H, Sundh I, Nilsson M (2001) Effect of climatic variability from 1980 to 1997 on simulated methane emission from a boreal mixed mire in northern Sweden. Global Biogeochemical Cycles, 15, 977-991.

Hammond RF (1981) The Peatlands of Ireland 60. Soil Survey Bulletin (2nd edn). An Foras Talúntais, Dublin.

Humphreys ER, Black TA, Morgenstern K, Li Z, Nesic Z (2005) Net ecosystem production of a Douglas-fir stand for 3 years following clearcut harvesting. Global Change Biology, 11, 450-464.

Kiely G, Leahy P, Sottocornola M, Laine AM, Mishurov M, Albertson J, Carton O (2009) CELTICFLUX: Measurement and Modelling of Greenhouse Gas Fluxes from Grasslands and a Peatland in Ireland Environmental Protection Agency. Available at http://erc.epa.ie/safer/iso19115/displayISO19115.jsp?isoID=62\#files (accessed 2 February 2010).

Koehler A-K, Murphy K, Kiely G, Sottocornola M (2009) Seasonal variation of DOC concentration and annual loss of DOC from an Atlantic blanket bog in South Western Ireland. Biogeochemistry, 95, 231-242.

Laine A, Sottocornola M, Kiely G, Byrne KA, Wilson D, Tuittila E-S (2006) Estimating net ecosystem exchange in a patterned ecosystem: example from blanket bog. Agricultural and Forest Meteorology, 138, 231-243.

Laine A, Wilson D, Kiely G, Byrne KA (2007) Methane flux dynamics in an Irish lowland blanket bog. Plant and Soil, 299, 181-193

Limpens J, Berendse F, Blodau C et al. (2008) Peatlands and the carbon cycle: from local processes to global implications - a synthesis. Biogeosciences, 5, 1475-1491.

Lund M, Lafleur PM, Roulet NT et al. (2009) Variability in exchange of $\mathrm{CO}_{2}$ across twelve northern peatland and tundra sites. Global Change Biology, doi: 10.1111/ j.1365-2486.2009.02104.x.

Moore TR, Roulet NT, Waddington MJ (1998) Uncertainty in predicting the effect of climatic change on the carbon cycling of Canadian peatlands. Climatic Change, 40, 229-245.

Morgenstern K, Andrew Black T, Humphreys ER et al. (2004) Sensitivity and uncertainty of the carbon balance of a Pacific Northwest Douglas-fir forest during an El Nino/La Nina cycle. Agricultural and Forest Meteorology, 123, 201-219.

Nilsson M, Sagerfors J, Buffam I et al. (2008) Contemporary carbon accumulation in a boreal oligotrophic minerogenic mire - a significant sink after accounting for all Cfluxes. Global Change Biology, 14, 2317-2332.

Proctor MCF (2006) Temporal variation in the surface-water chemistry of a blanket bog on Dartmoor, southwest England: analysis of 5 years'data. European Journal of Soil Science, 57, 167-178.

Roulet NT, Lafleur PM, Richard PJH, Moore TR, Humphreys ER, Bubier J (2007) Contemporary carbon balance and late Holocene carbon accumulation in a northern peatland. Global Change Biology, 13, 397-411

Sagerfors J, Lindroth A, Grelle A, Klemedtsson L, Weslien P, Nilsson M (2008) Annual CO exchange between a nutrient-poor, minerotrophic, boreal mire and the atmosphere. Journal of Geophysical Research - Biogeosciences, 113, G01001, doi: 10.1029/2006JG000306.

Schimel DS (1995) Terrestrial ecosystems and the carbon cycle. Global Change Biology, 1 , 77-91.

Sottocornola M, Kiely G (2005) An Atlantic Blanket Bog is a modest $\mathrm{CO}_{2}$ sink. Geophysical Research Letters, 32, L23804, doi: 10.1029/2005GL024731.

Sottocornola M, Kiely G (2010) Hydro-meteorological controls on the $\mathrm{CO}_{2}$ exchange variation in an Irish blanket bog. Agricultural and Forest Meteorology, 150, 287-297.

Sottocornola M, Laine A, Kiely G, Byrne KA, Tuittila E-S (2009) Vegetation and environmental variation in an Atlantic blanket bog in South-western Ireland. Plant Ecology, 203, 69-81.

Tarnocai C, Canadell JG, Schuur EAG, Kuhry P, Mazhitova G, Zimov S (2009) Soil organic carbon pools in the northern circumpolar permafrost region. Global Biogeochemical Cycles, 23

Tomlinson RW (2005) Soil carbon stocks and changes in the Republic of Ireland. Journal of Environmental Management, 76, 77-93. 
Turunen J, Roulet NT, Moore TR, Richard PJH (2004) Nitrogen deposition and increased carbon accumulation in ombrotrophic peatlands in Eastern Canada. Global Biogeochemical Cycles, 18, GB3002, doi: 10.1029/2003GB002154.

Turunen J, Tomppo E, Tolonen K, Reinikainen A (2002) Estimating carbon accumulation rates of undrained mires in Finland - application to boreal and subarctic regions. The Holocene, 12, 69-80.
Webb EK, Pearman GI, Leuning R (1980) Correction of flux measurements for density effects due to heat and water vapour transfer. Quarterly Journal of the Royal Meteorological Society, 106, 85-100.

Wind-Mulder HL, Rochefort L, Vitt DH (1996) Water and peat chemistry comparisons of natural and post-harvested peatlands across Canada and their relevance to peatland restoration. Ecological Engineering, 7, 161-181. 